www.jmscr.igmpublication.org

Impact Factor (SJIF): 6.379

Index Copernicus Value: 71.58

ISSN (e)-2347-176x ISSN (p) 2455-0450

crossref DOI: https://dx.doi.org/10.18535/jmscr/v6i6.107

Journal Of Medical Science And Clinical Research

\title{
Prevalence of Intestinal Parasitic Infection in Children of Slum Area of Dhanbad, Jharkhand
}

\author{
Authors \\ Dr Sujeet Kumar Tiwary ${ }^{1}$, Dr Binay Kumar Singh ${ }^{2 *}$, Dr Siyavar Sharan ${ }^{3}$ \\ Dr Sunil Kumar Sinha ${ }^{4}$, Dr Rajendra Kumar ${ }^{5}$ \\ ${ }^{1}$ Tutor, Microbiology, PMCH, Dhanbad \\ ${ }^{2,3}$ Associate Professor, Microbiology, PMCH, Dhanbad \\ ${ }^{4}$ Assistant Professor, P.S.M, PMCH, Dhanbad \\ ${ }^{5}$ Tutor, Physiology, PMCH, Dhanbad \\ *Corresponding Author \\ Dr Binay Kumar Singh \\ Associate Professor, Microbiology, PMCH, Dhanbad, Jharkhand, India
}

Abstract
The presence of intestinal parasitic infection in slum area children's is indicative of poor educational
background, Poor sanitation and unsafe drinking water increases the risk of parasitic infection.
Keywords: Anaemia, parasite, Worm, Trophozoites.

\section{Introduction}

Intestinal parasitic infection is a common health problem in slum areas of dhanbad children. The most common causes of intestinal parasites are through consumption of contaminated water, infected soil and improper hygiene. ${ }^{[1,2]}$ Parasites are most commonly causes gastrointestinal infection, such parasite can live anywhere in the body, but most preferably the intestinal wall. Intestinal parasite produce a variety of symptoms in those affected, most of which gastrointestinal complication include diarrhea, nausea, dysentery, abdominalpain, weight loss, and anaemia with general weakness. $^{[3,4]}$ this may also cause physical and mental disabilities, ${ }^{[7,8]}$ delayed growth in children. ${ }^{[5,6]}$ Poor sanitation and unsafe drinking water increases the risk of infestation of intestinal parasite ${ }^{[8,9]}$. This research was aimed at estimating the prevalence of intestinal parasite and its covers among children from 1-17 years of age in slum areas of dhanbad district.

\section{Method Sample collection}

This study shows the pattern of intestinal parasitic infection among anaemic children of slum areas of dhanbad district. A total of 1209 slum areas children of different age group both male and female (male 753 and 456female) are selected from different slum areas of dhanbad. All stoolsamples are collected and investigated through microscopically and Formalin ether sedimentation method, during 15 Feb 2016 to 14 Feb 2017. All data were analysed with standard statistical procedure. Result were presented in the form of tables\& column. 


\section{Sample collection}

All Stool samples were examined in the department of Microbiology laboratory at Patliputra Medical Collage and hospital dhanbad Jharkhand. All stool samples were collected in two wide mouths sterilised small Containers. One container was provided with $10 \%$ normal saline for its use Formalin ether sedimentation method. The specimen were first examined within one hour of collection.

\section{Data Collection}

All Data were analysed with standard statistical method, Percentage were computed for all variables. Result were presented in the form of table\& column.

\section{Result}

To this study shows overall infection percentage of $18.19 \%$ of which $9.76 \%$ showed mixed infection. All stool samples were microscopically examined and identified Entamoeba histolytica was the common $(29.54 \%)$ and Entamoeba coli was (21.84\%), Giardia lamblia(21.81\%), Ascaris lumbricoides (14.54.), Hymenolepis nana (8.18\%),.The prevalence rate for Enterobius vermicular is $(6.81 \%)$ and Trichuris trichiura $5.45 \%$, while Ancylostoma duodenale found in $4.0 \%$ and cases respectively.

\section{The following Laboratory methods were applied for the stool investigation:}

1. Direct stool smear examination in normal saline as well as in Gram's iodine to Identify trophozoites, cyst, eggs and larva.

2. Formalin ether sedimentation method used for stool concentration.

Table 1 Total Stool samples (Males, Females) positive cases percentage $(n=1209)$

\begin{tabular}{|l|c|c|c|}
\hline Gender & Number & Positive cases & Percentage \\
\hline Male & 753 & 127 & 10.50 \\
\hline Female & 456 & 93 & 07.69 \\
\hline Total & 1209 & 220 & 18.19 \\
\hline
\end{tabular}

Table 2: Total Number of positive Stool samples. (Types of intestinal parasite in positive cases $\mathrm{N}=220$ )

\begin{tabular}{|l|c|c|}
\hline Parasite. & Positive Cases & Percentage \\
\hline Entamoeba histolytica. & 65 & 29.54 \\
\hline Entamoeba coli. & 48 & 21.81 \\
\hline Giardia lamblia. & 32 & 14.54 \\
\hline Ascaries lumbricoides & 21 & 9.54 \\
\hline Hymenolepis nana. & 18 & 8.18 \\
\hline Enterobius Vermicularis & 15 & 6.81 \\
\hline Trichuris Trichiura. & 12 & 5.45 \\
\hline Ancylostoma duodenale & 09 & 4.0 \\
\hline Total & 220 & \\
\hline
\end{tabular}

Table 3: Total positive stool samples. (Mixed infection in children.)

\begin{tabular}{|l|c|c|}
\hline Parasites & $\begin{array}{c}\text { No.of } \\
\text { Children's }\end{array}$ & Percentage. \\
\hline $\begin{array}{l}\text { Entamoeba histolytica. With } \\
\text { Giardia lamblia. }\end{array}$ & 7 & $3.18 \%$ \\
\hline E.coli with A. lumbricoides & 6 & $2.72 \%$ \\
\hline E.coli with H nana & 5 & $2.5 \%$ \\
\hline $\begin{array}{l}\text { E.coli with H nana and } \\
\text { Entamoeba histolytica. }\end{array}$ & 3 & $1.36 \%$ \\
\hline Total & 21 & $9.76 \%$ \\
\hline
\end{tabular}

\section{Discussion}

In this study, we found Entamoeba histolytic dominant was $(29.54) \%$ in our finding, Entamoeba coli (21.84) was second prevalent in our study, The giardia lamblia was observed in 34 cases, Besides 09 cases of Ancylostoma duodenale were detected in children. This study suggests we should improve slum areas children's living conditions, availability of clean drinking water and good environment including give proper knowledge of hand washing after defecation. Our study recommend that measures like public awareness of the hazards of worm infection, personal hygiene, provision of safe drinking water supply and sanitation facility are important for prevention of parasitic diseases.

\section{Conclusion}

The primary focus was to study the high prevalence of Worm infection was found in a significant number of slum areas children of dhanbad district. Entamoeba histolitica was the commonest worm infection found in our study. This study suggests to improve slum areas 
children living conditions, availability of clean drinking water and good environment including proper knowledge of hand washing after defecation,

\section{References}

1. Steketee RW. Pregnancy, nutrition and parasitic diseases. J Nutr. 2003; 133:1661S-1667S. [PubMed].

2. Schistosomiasis and soil-transmitted helminth infections-preliminary estimates of the number of children treated with albendazole or mebendazole. Wkly Epidemiol Rec. 2006; 81:145-163. [PubMed

3. Curtale F, Pezzotti P, Sharbini AL, al Maadat H, Ingrosso P, et al. Knowledge, perceptions and behaviour of mothers toward intestinal helminths in Upper Egypt: implications for control. Health Policy Plan. 1998; 13:423-432. [PubMed]

4. Glickman LT, Camara AO, Glickman NW, McCabe GP. Nematode intestinal parasites of children in rural Guinea, Africa: prevalence and relationship to geophagia. Int J Epidemiol. 1999; 28:169174. [PubMed]

5. CDC. DPDx: Laboratory Identification of Parasites of Public Health Concern. Atlanta: Center for Disease Control \& Prevention, USA; 2006.

6. Sathian B, Sreedharan J, Baboo SN, Sharan K, Abhilash ES, Rajesh E. Relevance of Sample Size Determination in Medical Research. Nepal J Epidemiol. 2010; 1 (1): 4-10.

7. Khor GL.Update on the prevalence of malnutrition among children in Asia. Nepal Med Coll J. 2003 Dec; 5 (2): 11322.

8. Nathan DG, Orkin SH. Nathan and Oski's Haematology of infancy and childhood. $5^{\text {th }}$ ed. Vol 1. Philadelphia: WB Saunders; 1998: p 375-84.
9. Hercberg S, Galan P, Dupin H (Eds) Recent Knowledge on Iron and Folate Deficiencies in the World. Colloque INSERM Vol 197, Paris: INSERM, 1990; 209-15. 